\title{
Insights on Structure and Threshold Detection Limits of Stichtite (Magnesium-Chromium Carbonate-Hydroxide) by Fourier Transform Infrared Analysis
}

\author{
Erik Melchiorre $^{1,2, *}$, Andy Garcia ${ }^{1}$ and Maryjo Brounce ${ }^{2}$ \\ 1 Department of Geological Sciences, California State University of San Bernardino, 5500 University Parkway, \\ San Bernardino, CA 92407, USA; andy.garcia@csusb.edu \\ 2 Department of Earth and Planetary Sciences, University of California Riverside, 900 University Avenue, \\ Riverside, CA 92521, USA; maryjo.brounce@ucr.edu \\ * Correspondence: emelch@csusb.edu; Tel.: +1-909-537-7754
}

Received: 23 January 2020; Accepted: 25 February 2020; Published: 28 February 2020

\begin{abstract}
Spectral features for natural stichtite at 1042, 1096, 1360, 1638, and $3482 \mathrm{~cm}^{-1}$ provide insights on mineral structure, with peaks consistent with $\mathrm{OH}^{-}$stretching modes bound to $\mathrm{Mg}$ or $\mathrm{Cr}$, $\mathrm{CO}_{3}{ }^{2-}$ antisymmetric stretches and $\mathrm{CO}_{3}{ }^{2-}$ bound within the sample and molecular water. These Infrared (IR) data suggest natural stichtite forms at a $\mathrm{pH}$ of $>12$ with increased water and decreased carbonate in the interlayer due to a smaller interlayer distance and unit cell. Higher $\mathrm{pH}$ favors lower divalent cation purity and may explain observed ranges of non-end member compositions in stichtite from localities around the world, and across geologic time. This constrains stichtite formation to a range of very high $\mathrm{pH}$ conditions and is consistent with active serpentinizing fluid vents and some mine wastes. IR has clear application for the detection and quantification of stichtite under field and laboratory conditions within the detection limits of $5 \%$ stichtite within a serpentine host. The size and grade of terrestrial stichtite deposits, and resolution of remote sensing instruments, suggest remote IR detection of stichtite is possible, and remote IR detection for Earth and Mars is discussed.
\end{abstract}

Keywords: Fourier transform infrared (FTIR); stichtite; serpentine; threshold detection; interlayer

\section{Introduction}

Stichtite $\left(\mathrm{Mg}_{6} \mathrm{Cr}_{2}(\mathrm{OH})_{16}\left[\mathrm{CO}_{3}\right] \cdot 4 \mathrm{H}_{2} \mathrm{O}\right)$ is a purple to pink magnesium-chromium hydroxycarbonate mineral that may contain a fossil stable isotope record of early earth serpentinizing conditions under which the Last Universal Common Ancestor (LUCA) is known to have thrived [1-3]. Stichtite is an end member of the rhombohedral hydrotalcite group, which includes stichtite $(\mathrm{Cr})$, pyroaurite $(\mathrm{Fe})$, and hydrotalcite (Al). Stichtite has a waxy to pearly luster and has never been reported as macroscopic crystals, but occurs as fine, platy to acicular aggregates of crystallites to crystals typically less than 2 $\mathrm{mm}$ in the longest dimension. An excellent review of stichtite is found in Reference [4].

Stichtite is believed to form during active serpentinization, based upon the cross-cutting relations and intergrowth textures [5-7]. Serpentinization occurs when water-rock reactions drive the alteration of low-silica ultramafic rocks to form serpentine, hydrotalcite minerals, and other reaction products. This produces an environment with abundant electron donors, such as hydrogen gas and methane, and a high pH, e.g., [8,9]. Stichtite from the south Iberia Abyssal Plain in the Atlantic ocean, just offshore of the Spain-Portugal border, is known to form under these conditions at the expense of brucite and $\mathrm{Cr}$ spinel, based upon mineralogical evidence [10], presumably with the reaction $\mathrm{MgCr}_{2} \mathrm{O}_{4}+5 \mathrm{Mg}(\mathrm{OH})_{2}$ $+\mathrm{CH}_{4}+2 \mathrm{O}_{2}+5 \mathrm{H}_{2} \mathrm{O}=\mathrm{Mg}_{6} \mathrm{Cr}_{2}(\mathrm{OH})_{16}\left[\mathrm{CO}_{3}\right] \cdot 4 \mathrm{H}_{2} \mathrm{O}$. Similarly, stichtite may form through reaction 
of hydrogen gas and dissolved inorganic carbon (DIC) [11] with brucite and $\mathrm{Cr}$ spinel as $\mathrm{MgCr}_{2} \mathrm{O}_{4}$ $+5 \mathrm{Mg}(\mathrm{OH})_{2}+\mathrm{CO}_{3}{ }^{2-}+\mathrm{H}_{2}+6 \mathrm{H}_{2} \mathrm{O}=\mathrm{Mg}_{6} \mathrm{Cr}_{2}(\mathrm{OH})_{16}\left[\mathrm{CO}_{3}\right] \cdot 4 \mathrm{H}_{2} \mathrm{O}$, given that high $\mathrm{pH}$ conditions common to serpentinizing fluids should favor dissolved organic carbon as $\mathrm{CO}_{3}{ }^{2-}$.

Understanding the conditions that occur during active, modern serpentinization has greatly increased our knowledge of these systems and their role in supporting microbial life and the generation of methane, e.g., [12,13]. This, in turn, informs our understanding of possible sources of methane on modern and ancient Mars, and its implications for biosignatures, e.g., [9,14,15]. Geochemical results from recent work on active serpentinizing systems $[10,11]$ suggest conditions similar to those indicated by work on stichtite from Archean and Phanerozoic serpentinites [2,3].

Hydrotalcite minerals such as stichtite are known to store molecules such as peptides and amino acids within the hydrated interlayer between their brucite-like layers, e.g., [16-19]. As a carbonate, stichtite is likely to be among the most suitable of the serpentinization products for capture and preservation of direct-proxy carbon cycle biosignatures. However, questions remain about secondary formation of hydrotalcite minerals, and the potential environmental exchange of the loosely-bound contents of the interlayer, while the possibility of isotopic exchange for the contents of other more structurally bound signals in other portions of the stichtite structure remains unexplored [20,21].

If stichtite within serpentinite from fossil hydrothermal systems does preserve an isotope record of its conditions of formation, and harbor organic molecules in its interlayer, it would provide a window into conditions of habitable environments on early earth. As serpentinite is believed to occur in rocks from early Mars, e.g., [22,23] when water and an atmosphere were likely present, e.g., [24], it is possible that stitchtite may also be present, particularly in those rocks which were likely formed in the subsurface in closed systems and elevated temperatures, e.g., [25]. Here, we present infrared spectra of stitichtite and serpentine from the minerals' type locality at Stichtite Hill, Tasmania, Australia, in order to assess the extent to which trace stitchtite can be observed spectroscopically. While the mere presence of stichtite or other hydrotalcite minerals is not itself a biomarker, the ability to detect it remotely (e.g., through orbiter-mounted infrared spectroscopy) would mark an attractive target in the search for a record of life on early Earth and Mars. Thus it is important to determine the structural properties of stichtite which may harbor or preserve biomarkers, and determine the threshold at which remote sensing instrumentation like the Compact Reconnaissance Imaging Spectrometer for Mars (CRISM), and direct-contact instrumentation like Fourier transform infrared (FTIR), can distinguish the presence of stichtite in serpentinite.

\section{Geology and Mineralogy of Samples Used in this Study}

The stichtite occurrences of Tasmania, Australia are hosted by serpentinized mid-Cambrian ultramafic rocks known as the Dundas ultramafic complex [26,27]. This unit consists of heavily serpentinized ultramafic rocks, gabbros, and basaltic volcanic rocks. Three types of serpentinite are recognized in these rocks [28]. There are black serpentinites-these are unsheared, often contain abundant fine-grained magnetite, and are dominantly lizardite, which has replaced olivine-bearing ultramafic rocks. There are also green serpentinites, which are lizardite-chrysotile mixtures with localized deformation patterns and brecciation. Finally, there are sheared-contact serpentinites that consist mainly of chrysotile and rare antigorite, and may have formed during tectonic emplacement of the Adamsfield Ultramafic Complex [29]. All three of these serpentinite bodies lie within Middle to Late Cambrian strata. Stichtite mineralization occurs mainly within massive chromite-rich green serpentinite, and rarely within its border zones with black serpentinite [30]. Stichtite has a strong association with zones of brecciated green serpentinite [30].

Samples for this study come from the Stichtite Hill locality of Tasmania, Australia, which is the type location for this mineral species. Stichtite was first noted at this locality in 1891 [31], though it was another 23 years before it was properly described as a new species, because of miss-identification of the mineral [32]. All samples were collected by the authors from freshly mined material. 


\section{Materials and Methods}

\subsection{Sample Preparation and Characterization}

Whole-rock samples of green serpentinite with purple stichtite were collected from the Stichtite Hill locality described above (Figures 1 and 2). These samples were specifically selected from a location at the mine where the deepest excavations had exposed fresh material. Sample billets were cut from these rocks to expose fresh material just prior to sample preparation and analysis. Samples were selected to include a wide range of proportions of stichtite and serpentine minerals. Samples for scanning electron microscope energy dispersive analyses (SEM/EDX) and FTIR analyses were cut with a rock saw into $1-3 \mathrm{~cm}$ billets, ground flat, and polished to $0.2 \mu \mathrm{m}$ with alumina grit. Samples for $\mathrm{x}$-ray diffraction (XRD) analyses were broken off the larger billets described above. These chips were coarsely crushed and hand-picked to produce separate stichtite and serpentine concentrates which were then crushed to $<0.25 \mathrm{~mm}$. The concentrate was then processed with a Frantz vibro-magnetic separator to remove chromite and other impurities, then crushed to pass through a 100-mesh screen $(<0.147 \mathrm{~mm})$. Resulting powders were scanned by x-ray diffraction (XRD) to confirm mineralogy.

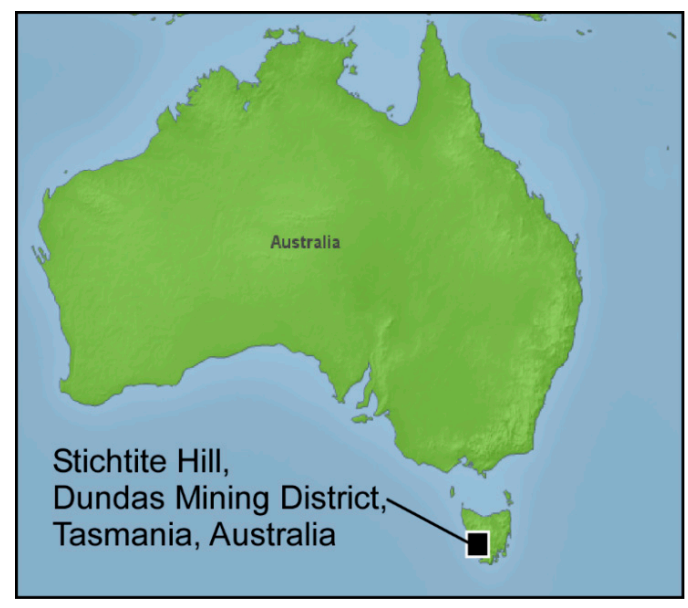

Figure 1. Sample location map, showing the location of Stichtite Hill and the Dundas Mining District, Tasmania, Australia (Black Square).

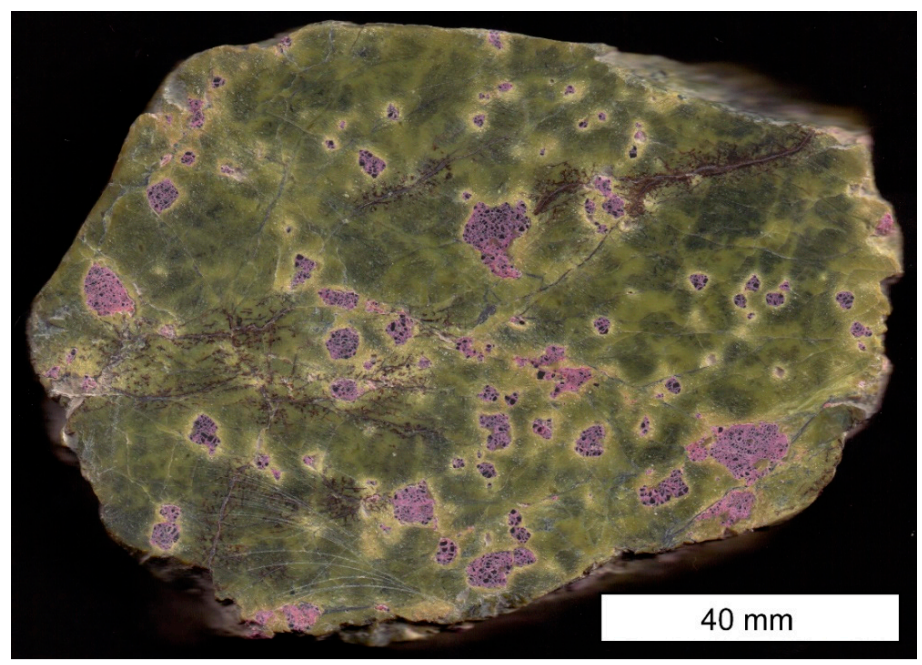

Figure 2. Large representative polished billet of serpentine-hosted stichtite. Slight variations in the shade of green for the serpentine result from slight variations $( \pm 4 \%)$ in the ratio of lizardite to chrysotile. Black veinlets within the green serpentine are magnetite. The purple stichtite domains contain silvery-black fragments of chromite. 


\subsection{Geochemical Analyses}

The XRD analyses were performed on a Philips X-Pert diffractometer (Philips Electronic Instruments, Inc., Mahwah, NJ, USA). A Philips Electronics Instruments Silicon Powder Standard (Type N: 52131) and an alpha quartz sample from Hot Springs, Arkansas were run as XRD standards. Centroid peak errors on the standards were \pm 0.00220 . In addition to XRD analyses, SEM/EDX was used to examine all polished samples to confirm mineralogy by chemistry and stoichiometry. A Phenom XL SEM (Fisher Scientific, Phoenix, AZ, USA) was used to capture secondary electron (SE) and backscatter electron (BSE) images using an acceleration voltage of 2 or $15 \mathrm{kV}$, respectively. The same instrument was used for energy dispersive X-ray (EDX) element measurements of major and minor element abundances, using standard off-peak interference and matrix corrections [33-38], and calibrations with registered standards provided by the manufacturer. The error associated with the in-situ element analyses is less than $\pm 2 \%$. Additional details on SE/BSE imaging and chemistry of samples from this locality are found in $[2,7]$.

The geochemical characterization of stichtite from the Stichtite Hill locality has been previously performed by many authors, e.g., [30,36,37] and is summarized in graphical and tabular form in Figure 5 and Table 2 in Reference [2]. Mineralogically, these correspond to a range of compositions from near endmember stichtite to iron- and aluminum-rich stichtite. Additionally, the crystal structure has been significantly refined within the hydrotalcite group, and the related species Barbertonite was discredited and recognized as Stichtite-2H by [35,38].

\subsection{FTIR Analyses}

Singly polished billets were analyzed via total reflectance Fourier transform infrared spectroscopy (FTIR) on a Thermo-Nicolet iS50 bench with Continuum Microscope attachment and a hemispherical silicon ATR crystal. The silicon crystal makes contact with the sample in $120 \mu \mathrm{m}$ diameter patches, and the incident beam samples $\sim 0.6 \mu \mathrm{m}$ depth at $2000 \mathrm{~cm}^{-1}$. Spectra were collected in nominally dry, $\mathrm{CO}_{2}$-free air produced from a Parker-Ballston purge-gas generator at $\sim 30 \mathrm{scfh}$, from 650 to $6000 \mathrm{~cm}^{-1}$ on a liquid nitrogen cooled MCT-A detector. Background spectra were collected in dry, $\mathrm{CO}_{2}$-free air (i.e., with no sample contact) and were subtracted from sample spectra shown in Figures 3-6.

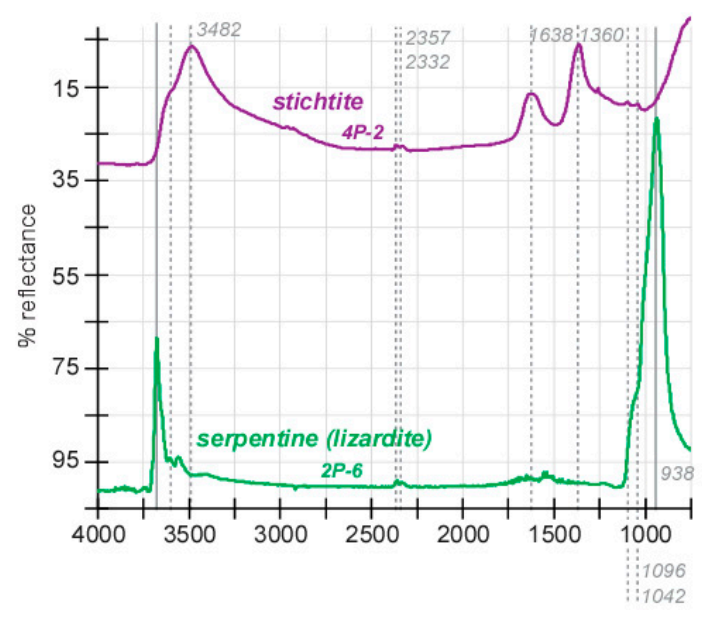

Figure 3. Plot of Fourier transform infrared spectroscopy (FTIR) spectra of stichtite (purple line) and its serpentine (lizardite) mineral host (green line). The peak positions in wavenumbers $\left(\mathrm{cm}^{-1}\right)$ for stichtite key features are marked with dashed vertical lines. Peak positions in wavenumbers $\left(\mathrm{cm}^{-1}\right)$ for key features in serpentine are marked with vertical solid lines. Peaks between 3700 and $3482 \mathrm{~cm}^{-1}$ correspond to $\mathrm{OH}^{-}$stretching modes. The $1638 \mathrm{~cm}^{-1}$ peak is a deformation mode of molecular $\mathrm{H}_{2} \mathrm{O}$. The $1360 \mathrm{~cm}^{-1}$ peak is a $\mathrm{CO}_{3}{ }^{2-}$ antisymmetric stretching mode. The $938 \mathrm{~cm}^{-1}$ peak corresponds to $\mathrm{Si}-\mathrm{O}$ vibrations in the $\mathrm{SiO}_{4}{ }^{2-}$ tetrahedron. 


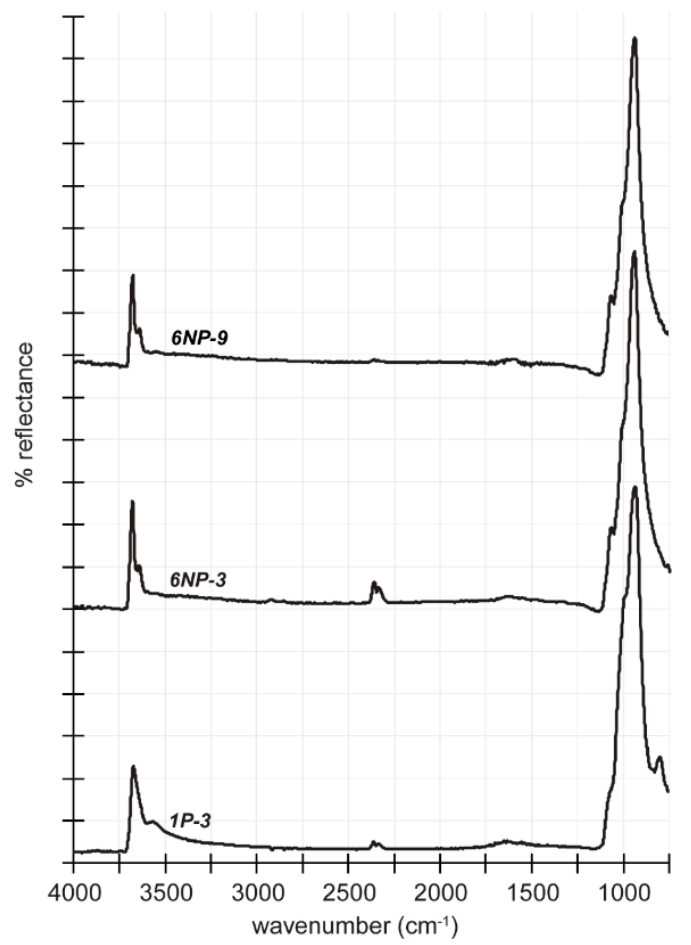

Figure 4. FTIR spectra for serpentine matrix in samples 6NP and 1P.

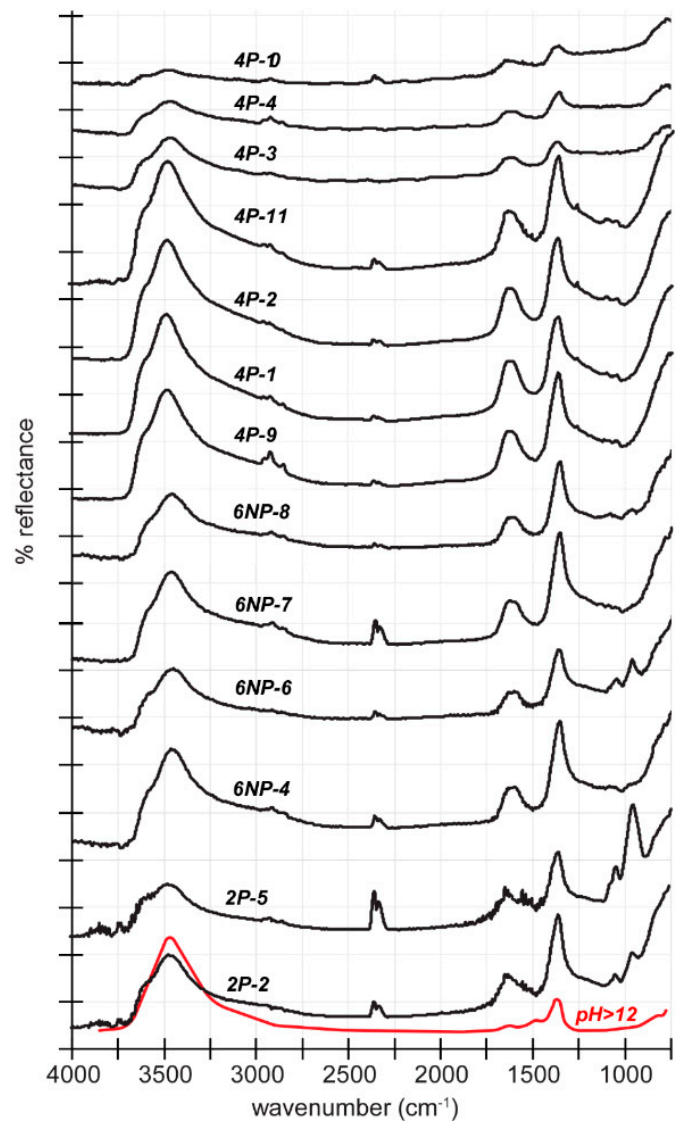

Figure 5. FTIR spectra for stichtite nodules in samples 2P, 6NP, 4P. Red spectra is a synthetic stichtite precipitated from fluids with $\mathrm{pH}>12$ [40]. 


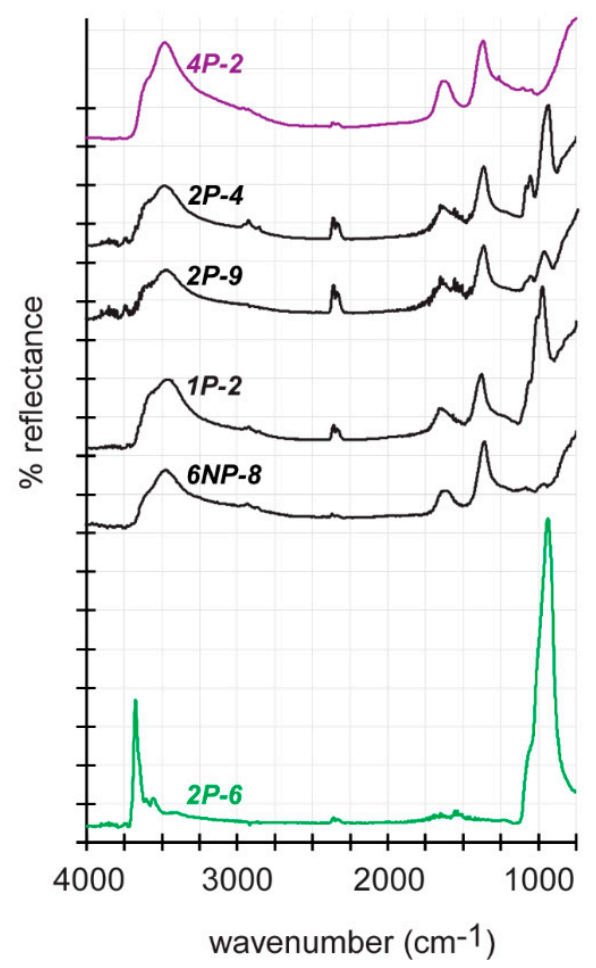

Figure 6. FTIR spectra from the boundary between stitchtite nodules and the serpentine-host, deliberately including both stitchtite and serpentine in the analyses volume, in samples $2 \mathrm{P}, 6 \mathrm{NP}$, and $1 \mathrm{P}$ (black lines). Also shown are the FTIR spectra of stichtite (purple line, top) and serpentine host (green line, bottom) from Figure 3.

\section{Results}

Three sets of stichtite-serpentine mineral separates from the Stichtite Hill locality were examined by XRD. All samples were confirmed as either stichtite or a mixture of serpentine minerals $(\sim 90 \%$ lizardite, $\sim 10 \%$ chrysotile) by XRD analysis. Examination of polished billets by SEM/EDX yielded major element chemistry and stoichiometry consistent with the presence of stichtite and serpentine mineralogy. In most samples, highly reflective domains of chromite within stichtite, and magnetite within serpentinite, were identified (Figure 2).

The results of FTIR analyses of unoriented stichtite and serpentine (i.e., lizardite $+/-$ chrysotile) are presented in Figures 3-6. Stichtite shows prominent and generally broad spectral features at $1042,1096,1360,1638$, and $3482 \mathrm{~cm}^{-1}$. The serpentine matrix shows prominent and generally narrow, intense spectral features at 938 and $3680 \mathrm{~cm}^{-1}$ (Figure 3). The group of peaks from $3680 \mathrm{~cm}^{-1}$ to $3482 \mathrm{~cm}^{-1}$ correspond to the position of peaks that arise from $\mathrm{OH}^{-}$stretching modes, where $\mathrm{OH}^{-}$ groups are bound to $\mathrm{Mg}$ (serpentine and stitchtite) or $\mathrm{Cr}$ (stitchtite). An intense peak due to $\mathrm{CO}_{3}{ }^{2-}$ antisymmetric stretches appears in stichtite at $1360 \mathrm{~cm}^{-1}$, which is absent in serpentine. This is 20 $\mathrm{cm}^{-1}$ lower than the previous measurements of synthetic stichtite (e.g., this peak is reported to appear at $1381 \mathrm{~cm}^{-1}$ by [39]), suggesting either (1) a compositional dependence on the cation identity bound to the carbonate anionic group and/or (2) an analytical dependence on the composition of the ATR crystal (diamond ATR in [39] versus a silicon ATR in this study). There are smaller doublets that appear. It is possible that these arise because of insufficient "background" subtraction, i.e., there is $\mathrm{CO}_{2}$ from atmosphere gases in the path of the IR beam that are not fully accounted for during the analysis. The doublet peaks at 1096 and $1042 \mathrm{~cm}^{-1}$ may be interpreted either as $\mathrm{CO}_{3}{ }^{2-}$ bound in the stichtite, or potentially is interference from nearby serpentine that is inadvertently included in the analytical volume. Because the analytical volume is relatively small relative to the size of some stichtite pods, we prefer the former interpretation. The stichtite spectra also shows a dominant peak at $1638 \mathrm{~cm}^{-1}$, which 
is a deformation mode of molecular water, and is not present in the measurements of the serpentine matrix. The serpentine matrix has a sharp, intense peak at $938 \mathrm{~cm}^{-1}$ with an apparent, lower intensity shoulder at higher wave numbers. This peak is absent in stitchtite analyses and is attributed to Si-O bond motions in the silica tetrahedron in lizardite $+/-$ chrysotile.

Measurements of regions in samples at the boundary between stichtite pods and serpentine matrix, contain all of the characteristic spectral features of stichtite, but also contain a peak at $938 \mathrm{~cm}^{-1}$, which is attributed to $\mathrm{Si}-\mathrm{O}$ bond stretches (e.g., 2P-4, 2P-9, 1P-2, 6NP-8; Figure 6). The intensity of the peak at $938 \mathrm{~cm}^{-1}$ varies, and the narrow peak at $3680 \mathrm{~cm}^{-1}$ observed in the serpentine matrix is not present in these mixed measurements (Figure 6). This suggests that these analyses contain a silicate mineral in the analysis volume, but that it lacks the highly ordered $\mathrm{Mg}-\mathrm{OH}$ stretches observed in the lizardite +/chrysotile serpentine matrix (Figures 3 and 4). One possibility is that these analyses contain traces of clinochore in addition to stichtite. Clinochore is known to be present in stichtite pods from the more altered samples from the same mine (Figure 3b in Reference [7]), present as veinlets that pervade and surround the stichtite matrix. Although the samples in this study were selected for freshness, the FTIR spectra suggest that perhaps incipient clinochore veins exist at the boundary between the serpentine matrix and stichtite pods (e.g., 2P-4, 2P-9, 1P-2, 6NP-8) and also within some stichtite pods (6NP-6, 2P-5, and 2P-2).

The key observation in this study is that the spectral features of the serpentine matrix and stichtite pods are distinct in both wavenumber position and spectral forms as the result of the variety of incorporation mechanisms for $\mathrm{H}, \mathrm{C}$, and $\mathrm{Si}$ in each mineral, and can be readily distinguished from one another with stichtite being prominent at concentrations as low as $5 \%$.

\section{Discussion}

\subsection{Structural and Geochemical Insights}

The stichtite spectral features at 1042, 1096, 1360, 1638, and $3482 \mathrm{~cm}^{-1}$ provide multiple insights on the structure of this mineral. The group of peaks at $3482 \mathrm{~cm}^{-1}$ is consistent with the peaks that arise from $\mathrm{OH}^{-}$stretching modes, where $\mathrm{OH}^{-}$groups would be bound to $\mathrm{Mg}$ or $\mathrm{Cr}$. The intense peak at $1360 \mathrm{~cm}^{-1}$ is consistent with $\mathrm{CO}_{3}{ }^{2-}$ antisymmetric stretches. The smaller doublets that appear in stichtite spectra at 1096 and $1042 \mathrm{~cm}^{-1}$ are interpreted as $\mathrm{CO}_{3}{ }^{2-}$ bound within the sample. The stichtite spectra also shows a dominant peak at $1638 \mathrm{~cm}^{-1}$ which is a deformation mode of molecular water. This is consistent with what is known about the structure of stichtite from other studies [4,39].

In addition to structural insights, the IR data provide suggestions on the chemical conditions under which stichtite may have formed. Experimental work by [36] has linked Cr-Zn hydrotalcite $\left(\mathrm{Mg}_{6} \mathrm{Al}_{2}\left(\mathrm{CO}_{3}\right)(\mathrm{OH})_{16} \cdot 4 \mathrm{H}_{2} \mathrm{O}\right)$ formation at increasing $\mathrm{pH}$ to increased water and decreased carbonate in the interlayer. This decrease in carbonate leads to decreased repulsive charges and decreased interlayer distance and unit cell.

Comparison of our IR data (Figure 4) with the experimental IR data in Figure 3 from [36] suggests that the Stichtite Hill samples formed at a $\mathrm{pH}$ of at least 12 . While it is no surprise that stichtite would form at very high $\mathrm{pH}$, given the known formation under serpentinizing conditions, e.g., [2,10,41,42], this does provide important supporting evidence for the conditions under which stichtite may form. It also suggests that the increased water and decreased carbonate in the interlayer associated with very high $\mathrm{pH}$ formation produces a smaller interlayer distance and unit cell for the samples we studied.

It has been puzzling for early researchers why stichtite occurs in only a few chromite-rich serpentinites, if it is indeed only a surface weathering product. It is now reported that stichtite and other hydrotalcite minerals will form as a surface weathering product when ultramafic mine tailing pore water has $\mathrm{pH} 8.4$ to 9.1 [38] and 8.8 to 9.4 [43]. It is also known that stichtite can form in active deep-sea submarine serpentinizing systems with pH 9 to 12.5 conditions $[10,11,44,45]$. Based on these observations, and the similarity of stichtite IR data for Stichtite Hill and synthetic hydrotalcite grown at $>12 \mathrm{pH}$, it seems most likely that stichtite formation is restricted to chromite-rich bodies with extremely 
high $\mathrm{pH}$. Furthermore, the inferred $>12 \mathrm{pH}$ conditions under which stichtite from Stichtite Hill is believed to have formed is most consistent with formation conditions found in active hydrothermal serpentinizing systems, and not the generally lower $\mathrm{pH}$ conditions found in most ultramafic mine tailing pore waters. This does not preclude formation of stichtite from weathering mine tailings, but serves as a tool by which it may be possible to determine the mode of formation from the rock record.

Additional work by [40] used a combination of synthesis experiments and IR analyses to determine that lower $\mathrm{pH}$ conditions favor higher divalent cation purity, while higher $\mathrm{pH}$ favors formation of metal oxides. This observation is significant for several reasons. First, it may explain the observed range of non-end member compositions observed in stichtite from localities around the world, and across geologic time [2,3]. While it is possible that these compositional trends may reflect the abundance of reactants within the serpentinizing system, it is also possible that this compositional variation is a record of serpentinizing fluid $\mathrm{pH}$. In host material with high porosity and permeability, such as ultramafic mine tailings, it has been demonstrated that stichtite can form as a weathering product, and exchange ions with the pore waters [42,43]. Future workers should explore the possibility of mapping spatially this potential fossil $\mathrm{pH}$ record for specific deposits, and examine the ion exchange capacity of this mineral, and specifically which sites may be prone to exchange, and which may bind ions more tightly.

Second, the "oxidation-reduction paradox" of formation of magnetite during serpentinization conditions of low oxygen fugacity and high partial pressures of hydrogen) [13] has been explained as a phenomena of grain boundary fluid buffering. Work by [40] determined experimentally and with FTIR studies that higher $\mathrm{pH}$ favors formation of metal oxides in competition with hydrotalcite, presenting a viable mechanism for the formation of the magnetite which is commonly found in close association with stichtite in serpentinite bodies. It is possible that the grain boundary buffering is mediated to some extent by the $\mathrm{pH}$ effects of metal oxide-hydrotalcite competition. The work of [41] established that serpentinite with abundant magnetite and Fe-poor brucite formed at temperatures of 200-300 ${ }^{\circ} \mathrm{C}$, while magnetite-poor samples with Fe-rich brucite formed at temperatures $<200{ }^{\circ} \mathrm{C}$. By analog to the above work and experimental FTIR studies, it is possible that thermal profiles of stichtite-rich serpentinizing vents may be generated by a combination of mapping Fe-substitution in stichtite and magnetite abundance at specific sites. Special focus on localities where stichtite and stichtite-2H (nee: Barbertonite) both occur such as Nevada Creek, Tasmania, Australia, and Barberton, South Africa may prove exceptionally rewarding as the $2 \mathrm{H}$ polytype of other hydrotalcite minerals is believed to form at higher temperatures [46].

\subsection{Determination of FTIR Detection Threshold for Stichtite in Serpentine and Implications for Astrobiology}

If stichtite preserves a faithful isotopic record of the conditions in which it formed during the Archean to Neo-Cambrian, and given the modern association of this type of environment with primitive chemosynthetic Archea, it is an exciting possibility that stichtite may record biosignatures from early earth, e.g., [3]. As serpentinizing environments are known to exist on Mars, it is further possible that hydrotalcite minerals such as stichtite may preserve past or present biosignatures within Martian serpentinite terrains.

The determination that stichtite formation is associated with potentially habitable environments, and may record these conditions and their carbon sourcing as far back as the Archean will have utility for interpretation of potential biosignatures on Mars. The possibility that stichtite may also preserve an isotopic and geochemical record from both deep-Earth time in tightly-bound structural sites, and a more recent signal from a loosely-bound interlayer that is more readily exchanged, could provide a powerful time-vector for biological change [21].

The requirements for serpentinization are simply heat, water, and mafic rock. Serpentinite is known to occur in rocks from early Mars, e.g., [22,23], when water, heat flow, and an atmosphere were likely present over large mafic bedrock terrains, e.g., [24]. Serpentinization would have generated $\mathrm{H}_{2}$ and methane which are known energy sources for the earliest chemosythetic life on earth [1]. A record 
of these habitable environments on Mars may be preserved within stichtite or other hydrotalcite minerals in these serpentinite rocks. The association of modern excess methane with these same terrains should be used to supplement existing evidence for site selection of future Mars sample cache/return missions, as well as instrumentation choice [47], as the best analog between Earth and Mars may be found by viewing the past and present habitable environmental conditions through the lens of deep-earth time during terrestrial serpentinization, when known biological systems were more primitive, e.g., [48].

The use of IR has clear application for the detection and quantification of minor amounts of stichtite under field and laboratory conditions. At both the hand-sample scale (Figure 2) and outcrop scale (Figure 7), stichtite abundance is typically well above $5 \%$ of the serpentine host for the brecciated pipes within which it occurs. At the Stichtite Hill, Tunnel Hill, and Nevada Creek localities in Tasmania, Australia, stichtite is observed to locally comprise over $50 \%$ of the rock at the scale of 0.1 to $1 \mathrm{~m}$ (Figure 7), with a footprint of up to $100 \mathrm{~m}$ for abundances at the 5\% cutoff. Assuming that stichtite deposit formation would be similar on Mars, and given the resolution of existing instrumentation, this suggests that IR spectra from both remote sensing and lander/rover missions will have the potential to detect stichtite within serpentinite terrains.

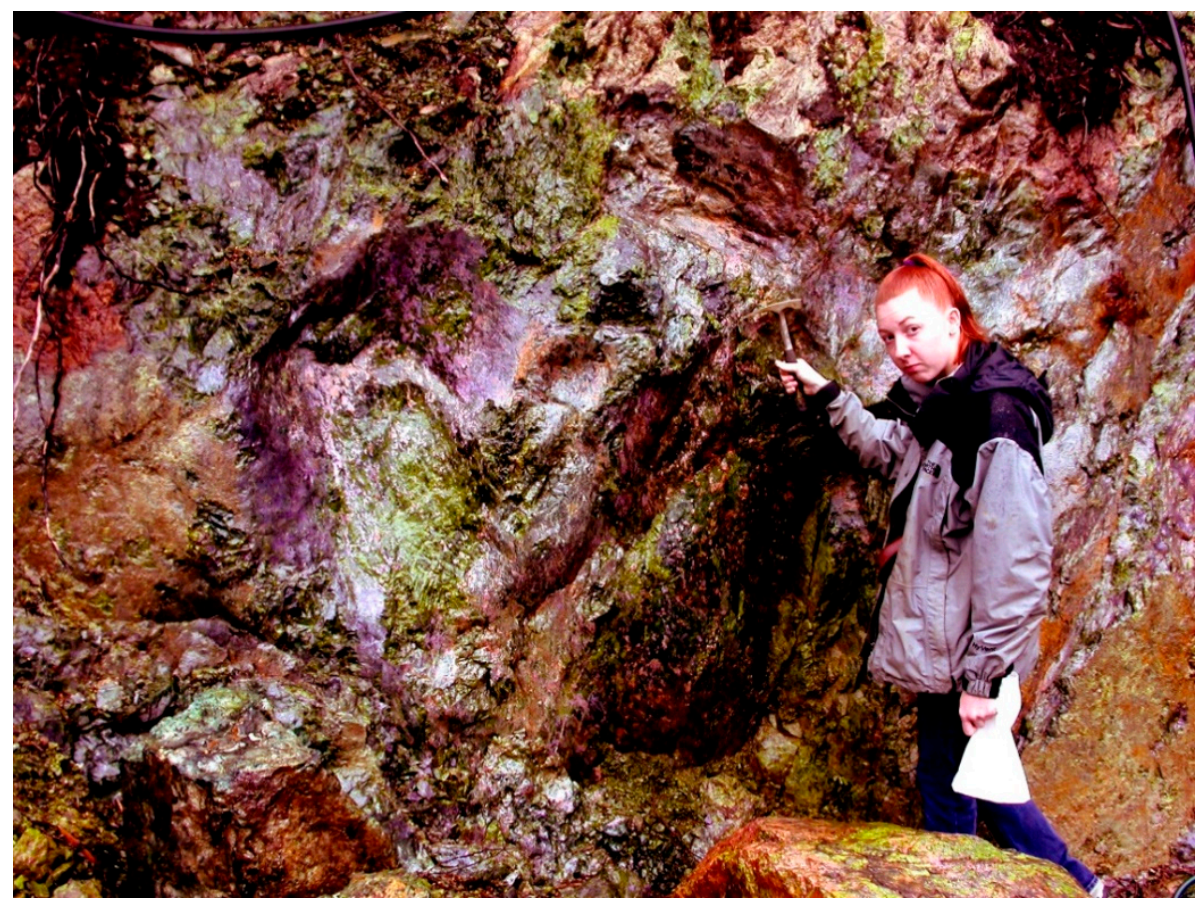

Figure 7. Outcrop-scale photograph of stichtite occurrence and abundance at Stichtite Hill, Tasmania, Australia. Stichtite (purple areas) constitute about $50 \%$ of this outcrop, with the balance being serpentine (shades of green) and pyroaurite (brownish-red). Geologist is $1.6 \mathrm{~m}$ tall.

If stichtite records biosignatures and formation conditions from early earth it may also record conditions of formation in serpentinizing environments that are known to exist on Mars. The use of IR has clear application for the detection and quantification of minor amounts of stichtite under field and laboratory conditions. At both the hand-sample scale and outcrop scale, stichtite abundance is typically well above the IR detection limits of $5 \%$ of the serpentine host. With a typical stichtite deposit footprint of up to $10,000 \mathrm{~m}^{2}$ for abundances at the $5 \%$ cutoff, and given the resolution of existing instrumentation, this suggests that IR spectra from both remote sensing and lander/rover missions will have the potential to detect stichtite within the serpentinite terrains on Mars. 


\section{Conclusions}

Stichtite spectral features at 1042, 1096, 1360, 1638, and $3482 \mathrm{~cm}^{-1}$ provide insights on mineral structure. Peaks at $3482 \mathrm{~cm}^{-1}$ are consistent with $\mathrm{OH}^{-}$stretching modes, where $\mathrm{OH}^{-}$groups would be bound to $\mathrm{Mg}$ or $\mathrm{Cr}$. The $1360 \mathrm{~cm}^{-1}$ peak is consistent with $\mathrm{CO}_{3}{ }^{2-}$ antisymmetric stretches, and smaller doublets at 1096 and $1042 \mathrm{~cm}^{-1}$ are interpreted as $\mathrm{CO}_{3}{ }^{2-}$ bound within the sample. The dominant stichtite peak at $1638 \mathrm{~cm}^{-1}$ is a deformation mode of molecular water.

In addition to structural insights, the IR data suggests constraints on the chemical conditions under which stichtite may have formed, as experimental work has linked increasing $\mathrm{pH}$ to increased water and decreased carbonate in the interlayer of hydrotalcite. This decrease in carbonate leads to decreased repulsive charges and decreased interlayer distance and unit cell. Comparison of our IR data with IR data from [40] suggests that natural stichtite formed at a $\mathrm{pH}$ of $>12$. While it is no surprise that stichtite would form at very high $\mathrm{pH}$, given the known formation under serpentinizing conditions, this does provide important evidence for conditions of stichtite formation. It also suggests that the increased water and decreased carbonate in the interlayer associated with very high $\mathrm{pH}$ formation produces a smaller interlayer distance and unit cell for the samples we studied.

Additional work by [40] determined that lower $\mathrm{pH}$ conditions favor higher divalent cation purity, while higher $\mathrm{pH}$ favors formation of metal oxides. This observation may explain the observed range of non-end member compositions observed in stichtite from localities around the world, and across geologic time. While it is possible that these compositional trends may reflect the abundance of reactants within the serpentinizing system, it is also possible that this compositional variation is a record of serpentinizing fluid $\mathrm{pH}$. If so, the wide compositional trends seen in stichtite from Tasmania and Mt. Keith Australia, Mexico, and South Africa may link stichtite formation to a range of very low $\mathrm{pH}$ conditions.

It is puzzling why stichtite occurs in few of the many chromite-rich serpentinites, if it is indeed only a surface weathering product. Stichtite and other hydrotalcite minerals will form as a surface weathering product when pore water $\mathrm{pH}$ is elevated, but it is also known that stichtite can form in active deep-sea serpentinizing systems with elevated $\mathrm{pH}$. Based on these observations, the wide-ranging composition of stichtite, and the similarity of stichtite IR data for Stichtite Hill and synthetic hydrotalcite grown at $>12 \mathrm{pH}$, it seems most likely that stichtite formation is restricted to chromite-rich bodies with extremely high $\mathrm{pH}$. This is most consistent with formation conditions found in active hydrothermal serpentinizing systems, and less commonly the generally lower $\mathrm{pH}$ conditions found in most ultramafic mine tailing pore waters. This does not preclude formation of stichtite from weathering mine tailings.

Author Contributions: Conceptualization and methodology, E.M. and M.B.; analysis and field work, E.M. and A.G.; funding acquisition and instrumentation support, M.B. and E.M.; writing-original draft preparation, review and editing, visualization, E.M., M.B., and A.G.; supervision and project administration, M.B. and E.M. All authors have read and agreed to the published version of the manuscript.

Funding: Instrumentation was provided and supported by the National Science Foundation, EAR-0115884 and EAR-0941106 (E.M.) and the University of California (M.B.). Support of SEM, EDX, and XRD instrumentation was by a California State University VETI grant (E.M., Tim Usher, and Codi Lazar). Support was provided by a NASA Astrobiology Institute Minority Institution Research Sabbatical (NAI-MIRS) program award to one of the authors (E.M.), and his student (A.G.).

Acknowledgments: We thank Mike and Eleanor Phelan for providing access to their mining properties, being generous hosts, and providing valuable insights on stichtite occurrence gained from decades of experience on mining stichtite for collectors and ornamental use. We also thank Ralph Bottrill (Mineral Resources Tasmania), Sue Koepke, and Geert Buters (both Mineralogical Society of WA) for support in the field and valuable discussions on the occurrence and origins of stichtite. Students Kahn Luu, Samantha Harris, and Zach Freeman assisted with fieldwork and lab work as a senior project at CSUSB. The lead author also thanks his colleagues in the Minority Institution Astrobiology Collaborative (MiAC), and the astrobiology teams at UC Riverside and University of Hawaii for providing a supportive network and environment which made this work possible.

Conflicts of Interest: The authors declare no conflict of interest. The funders had no role in the design of the study; in the collection, analyses, or interpretation of data; in the writing of the manuscript, or in the decision to publish the results. 


\section{References}

1. Weiss, M.C.; Sousa, F.L.; Mrnjavac, N.; Neukirchen, S.; Roettger, M.; Nelson-Sathi, S.; Martin, W.F. The physiology and habitat of the last universal common ancestor. Nature Microbio. 2016, 1, 16116. [CrossRef] [PubMed]

2. Melchiorre, E.B.; Bottrill, R.; Huss, G.R.; Lopez, A. Conditions of stichtite $\left(\mathrm{Mg}_{6} \mathrm{Cr}_{2}(\mathrm{OH})_{16}\left[\mathrm{CO}_{3}\right] \cdot 4 \mathrm{H}_{2} \mathrm{O}\right)$ formation and its geochemical and isotope record of early phanerozoic serpentinizing environments. Geochim. Cosmochim. Acta 2017, 197, 43-61. [CrossRef]

3. Melchiorre, E.B.; Bottrill, R.; Huss, G.R.; Lopez, A. The early Earth geochemical and isotope record of serpentinizing environments from Archean stichtite $\left(\mathrm{Mg}_{6} \mathrm{Cr}_{2}(\mathrm{OH}) 16\left[\mathrm{CO}_{3}\right] 4 \mathrm{H}_{2} \mathrm{O}\right)$. Precamb. Res. 2018, 310, 198-212. [CrossRef]

4. Theiss, F.L.; Ayoko, G.A.; Frost, R.L. Stichtite: A review. Clay Miner. 2013, 48, 143-148. [CrossRef]

5. Varadarajan, S. Stichtite from the ultramafics of Nuggihalli schist belt, Mysore state (abstract). In Proceedings of the Indian Science Congress, 53rd Session, Chandigarh, India, 3 March 1966; Volume 3, p. 183.

6. Melchiorre, E.B.; Lopez, A. Stichtite, and chromium mineralization within methane rich serpentinizing environments. In Proceedings of the 11th SGA Biennial Meeting, Antofagasta, Chile, 26-29 September 2011; pp. 169-171.

7. Melchiorre, E.B.; Huss, G.R.; Lopez, A. Carbon and hydrogen stable isotope microanalysis and data correction for rare carbonate minerals: Case studies for stichtite $\left(\mathrm{Mg}_{6} \mathrm{Cr}_{2}\left[(\mathrm{OH})_{16} \mid \mathrm{CO}_{3}\right] \cdot \mathrm{H}_{2} \mathrm{O}\right)$ and malachite $\left(\mathrm{Cu}_{2} \mathrm{CO}_{3}(\mathrm{OH})_{2}\right)$. Chem. Geol. 2014, 367, 63-69. [CrossRef]

8. Proskurowski, G.; Lilley, M.D.; Seewald, J.S.; Früh-Green, G.L.; Olson, E.J.; Lupton, J.E.; Sylva, S.P.; Kelley, D.S. Abiogenic hydrocarbon production at lost city hydrothermal field. Science 2008, 319, 604-607. [CrossRef]

9. McCollom, T.M.; Seewald, J.S. Serpentinites, hydrogen, and life. Elements 2013, 9, 129-134. [CrossRef]

10. Klein, F.; Humphris, S.E.; Guo, W.; Schubotz, F.; Schwarzenbach, E.M.; Orsi, W.D. Fluid mixing and the deep biosphere of a fossil Lost City-type hydrothermal system at the Iberia Margin. Proc. Nat. Acad. Sci. 2015, 112, 12036-12041. [CrossRef]

11. Mottl, M.J.; Komor, S.C.; Fryer, P.; Moyer, C.L. Deep-slab fluids fuel extremophilic Archaea on a Mariana forearc serpentinite mud volcano: Ocean Drilling Program Leg 195. Geochem. Geophys. Geosyst. 2003, 4, 1-14. [CrossRef]

12. Etiope, G.; Sherwood-Lollar, B. Abiotic methane on Earth. Rev. Geophys. 2013, 51, 276-299. [CrossRef]

13. Evans, B.W.; Hattori, K.; Baronnet, A. Serpentinite: What, why, where? Elements 2013, 9, 99-106. [CrossRef]

14. Parnell, J.; Boyce, A.J.; Blamey, N.J. Follow the methane: The search for a deep biosphere, and the case for sampling serpentinites, on Mars. Intern. J. Astrobio. 2010, 9, 193-200. [CrossRef]

15. Etiope, G.; Ehlmann, B.L.; Schoell, M. Low temperature production and exhalation of methane from serpentinized rocks on Earth: A potential analog for methane production on Mars. Icarus 2013, 224, $276-285$. [CrossRef]

16. Newman, S.P.; Di Cristina, T.; Coveney, P.V.; Jones, W. Molecular dynamics simulation of cationic and anionic clays containing amino acids. Langmuir 2002, 18, 2933-2939. [CrossRef]

17. Kottegoda, N.S.; Jones, W. Preparation and characterisation of Li-Al-glycine layered double hydroxides (LDHs)-polymer nanocomposites. Macromol. Symp. 2005, 222, 65-71. [CrossRef]

18. Gerstel, P.; Hoffmann, R.C.; Lipowsky, P.; Jeurgens, L.P.H.; Bill, J.; Aldinger, F. Mineralization from aqueous solutions of zinc salts directed by amino acids and peptides. Chem. Mat. 2006, 18, 179-186. [CrossRef]

19. Del Hoyo, C. Layered double hydroxides and human health: An overview. Appl. Clay Sci. 2007, 36, $103-121$. [CrossRef]

20. Bouzaid, J.; Frost, R. Thermal decomposition of stichtite. J. Therm. Anal. Cal. 2007, 89, 133-135. [CrossRef]

21. Turvey, C.C.; Wilson, S.A.; Hamilton, J.L.; Tait, A.W.; McCutcheon, J.; Beinlich, A.; Fallon, S.J.; Dipple, G.M.; Southam, G. Hydrotalcites and hydrated Mg-carbonates as carbon sinks in serpentinite mineral wastes from the Woodsreef chrysotile mine, New South Wales, Australia: Controls on carbonate mineralogy and efficiency of $\mathrm{CO}_{2}$ air capture in mine tailings. Intern. J. Greenh. Gas Cont. 2018, 79, 38-60. [CrossRef]

22. Viviano, C.E.; Moersch, J.E.; McSween, H.Y. Implications for early hydrothermal environments on Mars through the spectral evidence for carbonation and chloritization reactions in the Nili Fossae region. J. Geophys. Res. Planets 2013, 118, 1858-1872. [CrossRef] 
23. Amador, E.S.; Bandfield, J.L. Elevated bulk-silica exposures and evidence for multiple aqueous alteration episodes in Nili Fossae, Mars. Icarus 2016, 276, 39-51. [CrossRef]

24. Haberle, R.M.; Clancy, R.T.; Forget, F.; Smith, M.D.; Zurek, R.W. The Atmosphere and Climate of Mars; Cambridge University Press: Cambridge, UK, 2017; Volume 18, 588p.

25. Ehlmann, B.L.; Mustard, J.F.; Murchie, S.L.; Bibring, J.P.; Meunier, A.; Fraeman, A.A.; Langevin, Y. Subsurface water and clay mineral formation during the early history of Mars. Nature 2011, 479, 53. [CrossRef] [PubMed]

26. Brown, A.V. Geology of the Dundas-Mow1t Lindsay-Mount Youngback region. Tasman. Dep. Mines 1986, Geological Survey Bulletin 62,1-89.

27. Burrett, C.F.; Martin, E.L. Geology and Mineral Resources of Tasmania: Maps (No. 15); Geological Society of Australia: Hornsby, Australia, 1989; 1 sheet.

28. Rubenach, M.J. The origin and emplacement of the Serpentine Hill complex, western Tasmania. J. Geol. Soc. Austr. 1974, 21, 91-106. [CrossRef]

29. Varne, R.; Brown, A.V. The geology and petrology of the Adamsfield ultramafic complex, Tasmania. Contr. Mineral. Pet. 1978, 67, 195-207. [CrossRef]

30. Bottrill, R.S.; Graham, I.T. Stichtite from western Tasmania. Austr. J. Mineral. 2006, 12, 101-107.

31. Petterd, W.F. Catalogue of the Minerals of Tasmania; Examiner Press: Launceston, Australia, 1896; p. 72.

32. Twelvetrees, W.H. Stichtite: A new Tasmanian mineral. Tasman. Dep. Minesgeol. Surv. Rec. 1914, 2, 11.

33. Armstrong, J.T. Quantitative analysis of silicates and oxide minerals: Comparison of Monte-Carlo, ZAF and Phi-Rho-Z procedures. In Proceedings of the 23rd Annual Conference of the Microbeam Analysis Society, Milwaukee, Wisconsin, 8-12 August 1988; D.E., Ed.; Microbeam Analysis Society: San Francisco, CA, USA, 1988; pp. 239-246.

34. Donovan, J.J.; Snyder, D.A.; Rivers, M.L. An improved interference correction for trace element analysis. Microb. Anal. 1993, 2, 23-28.

35. Mills, S.J.; Whitfield, P.S.; Wilson, S.A.; Woodhouse, J.N.; Dipple, G.M.; Raudsepp, M.; Francis, C.A. The crystal structure of stichtite, re-examination of barbertonite, and the nature of polytypism in $\mathrm{MgCr}$ hydrotalcites. Am. Min. 2011, 96, 179-187. [CrossRef]

36. Ashwal, L.D.; Cairncross, B. Mineralogy and origin of stichtite in chromite-bearing serpentinites. Contrib. Min. Petr. 1997, 127, 75-86. [CrossRef]

37. Frondel, C. Constitution and polymorphism of the pyroaurite and sjogrenite groups. Amer. Min. J. Earth Planet. Mat. 1941, 26, 295-315.

38. Mills, S.J.; Christy, A.G.; Génin, J.M.; Kameda, T.; Colombo, F. Nomenclature of the hydrotalcite supergroup: Natural layered double hydroxides. Min. Mag. 2012, 76, 1289-1336. [CrossRef]

39. Frost, R.; Erickson, K. Vibrational spectroscopy of stichtite: Spectrochimica Acta Part A: Molecular and Biomolecular. Spectroscopy 2004, 60, 3001-3005. [CrossRef]

40. Kloprogge, J.T.; Hickey, L.; Frost, R.L. The effect of varying synthesis conditions on zinc chromium hydrotalcite: A spectroscopic study. Mater. Chem. Phys. 2005, 89, 99-109. [CrossRef]

41. Klein, F.; Bach, W.; Humphris, S.E.; Kahl, W.A.; Jöns, N.; Moskowitz, B.; Berquó, T.S. Magnetite in seafloor serpentinite-Some like it hot. Geology 2014, 42, 135-138. [CrossRef]

42. Oskierski, H.C.; Dlugogorski, B.Z.; Oliver, T.K.; Jacobsen, G. Chemical and isotopic signatures of waters associated with the carbonation of ultramafic mine tailings, Woodsreef Asbestos Mine, Australia. Chem. Geol. 2016, 436, 11-23. [CrossRef]

43. Hamilton, J.L.; Wilson, S.A.; Morgan, B.; Turvey, C.C.; Paterson, D.J.; Jowitt, S.M.; McCutcheon, J.; Southam, G. Fate of transition metals during passive carbonation of ultramafic mine tailings via air capture with potential for metal resource recovery. Int. J. Greenh. Gas Cont. 2018, 71, 155-167. [CrossRef]

44. Kelley, D.S.; Karson, J.A.; Blackman, D.K.; FruÈh-Green, G.L.; Butterfield, D.A.; Lilley, M.D.; Olson, E.J.; Schrenk, M.O.; Roe, K.K.; Lebon, G.T.; et al. An off-axis hydrothermal vent field near the Mid-Atlantic Ridge at $30 \mathrm{~N}$. Nature 2001, 412, 145. [CrossRef]

45. Lang, S.Q.; Butterfield, D.A.; Schulte, M.; Kelley, D.S.; Lilley, M.D. Elevated concentrations of formate, acetate and dissolved organic carbon found at the Lost City hydrothermal field. Geochim. Cosmochim. Acta 2010, 74, 941-952. [CrossRef]

46. Kloprogge, J.T.; Frost, R.L. Fourier transform infrared and Raman spectroscopic study of the local structure of Mg-, Ni-, and Co-hydrotalcites. J. Solid St. Chem. 1999, 146, 506-515. [CrossRef] 
47. Vago, J.L.; Westall, F.; Coates, A.J.; Jaumann, R.; Korablev, O.; Ciarletti, V.; Mitrofanov, I.; Josset, J.L.; De Sanctis, M.C.; Bibring, J.P.; et al. Habitability on early Mars and the search for biosignatures with the ExoMars Rover. Astrobiology 2017, 17, 471-510. [CrossRef] [PubMed]

48. Lyons, T.W.; Reinhard, C.T.; Planavsky, N.J. The rise of oxygen in Earth's early ocean and atmosphere. Nature 2014, 506, 307-315. [CrossRef] [PubMed]

(C) 2020 by the authors. Licensee MDPI, Basel, Switzerland. This article is an open access article distributed under the terms and conditions of the Creative Commons Attribution (CC BY) license (http://creativecommons.org/licenses/by/4.0/). 